Cahiers d'études africaines

\title{
Creating a Socialist Intelligentsia
}

Soviet Educational Aid and its Impact on Africa (1960-1991)

\section{Constantin Katsakioris}

\section{(2) OpenEdition}

\section{Journals}

Electronic version

URL: http://journals.openedition.org/etudesafricaines/20664

DOI: 10.4000/etudesafricaines.20664

ISSN: $1777-5353$

\section{Publisher}

Éditions de l'EHESS

\section{Printed version}

Date of publication: 1 July 2017

Number of pages: $259-288$

ISBN: 978-2-7132-2688-5

ISSN: 0008-0055

\section{Electronic reference}

Constantin Katsakioris, « Creating a Socialist Intelligentsia », Cahiers d'études africaines [Online], 226 |

2017, Online since 01 April 2019, connection on 02 January 2020. URL : http://

journals.openedition.org/etudesafricaines/20664 ; DOI : 10.4000/etudesafricaines.20664 


\title{
Creating a Socialist Intelligentsia
}

\author{
Soviet Educational Aid and its Impact on Africa \\ (I960-199I)
}

On June $1^{\text {st }}$, 1951, the Secretary General of the Nigerian Trade Union of Agricultural and Forestry Workers, Ilio Bosi, addressed a letter to the head of the World Federation of Trade Unions, the Frenchman Louis Saillant, with a concrete request. After thanking him for the scholarships Nigerians had been granted by East Germany, Bosi praised the work of his fellow trade unionist Nduka Eze and asked for a scholarship that would allow Eze to pursue his studies "in the School of Political Sciences and Economics of Moscow University." 1 The letter reached Moscow soon afterwards yet, as was the case with other similar early African requests, this one was not met with approval. The issue of scholarships was repeatedly raised by delegations from colonial Africa, which had started visiting the USSR, after the death of Joseph Stalin (1953), the Soviet endorsement of the Bandung Conference (1955) and of the Afro-Asian movement. Nevertheless, as historians Apollon Davidson and Sergey Mazov (1999: 158-168, 324-327) have documented, the decisions to foster political and cultural ties with SubSaharan Africa and to offer Africans scholarships for study at Soviet universities were taken by the Communist Party of the Soviet Union (CPSU) only between 1958 and 1959, and implemented without delay. In September 1960, the famous Peoples' Friendship University (Universitet Družby Narodov, hereafter "UDN"), a school reserved for students from "developing countries," opened its doors in Moscow and welcomed 179 Africans, as well as 231 Asians, 182 Latin Americans, and 60 more students from the countries of the Middle East. In February 1961, it was renamed "Patrice Lumumba" after the late Congolese leader.

Symbolically and, in many respects, literally, the creation of the UDNPatrice Lumumba University ushered in a new era of Soviet-African and, more broadly, of Soviet-Third World relations. Educational aid to Africa, on which this paper concentrates, became a major part of the overall Soviet developmental aid. Provided either by the UDN and numerous other schools

1. State Archive of the Russian Federation (hereafter GARF), f. (fond means collection) 5451, op. (opis' is inventory) 45, d. (delo is file) 503, l. (list means page) 40-43. 
in the USSR, or, to a lesser extent, through the creation of educational centers and the dispatch of Soviet professors to Africa, this aid was meant to put into practice Leninist principles of solidarity with the "oppressed countries" and the "oppressed classes," both victims of Western imperialism. As the First Secretary of the CPSU, Nikita Khrushchev proclaimed at the opening ceremony of the UDN that the Soviet Union "sympathized with the aims of Asian, African, and Latin American peoples to develop their economies and to train their own engineers, agronomists, doctors, and scientists" (MID SSSR 1963: 83). Besides internationalist proclamations, powerful ideological and geopolitical considerations motivated "the Soviet cultural offensive" (Barghoorn 1960: 188-225), whose goal was ultimately to create a socialistminded and pro-Soviet intelligentsia in the postcolonial world. The outcome, in terms of students' training, was particularly significant. From 1960 to the dissolution of the USSR in December 1991, more than 43,500 students from Sub-Saharan Africa received post-secondary education in the motherland of socialism, the overwhelming majority studied in universities and higher technological or medical schools. Throughout the Cold War, the USSR thus became a major host country for African students, competing with and even outdoing a former colonial power such as the United Kingdom (see Appendix) by welcoming more students.

At the same time, the Soviet cultural offensive did not remain unanswered. Mainly in response to the communist threat, former colonial powers, as well as the United States, Canada and other developed capitalist countries offered developmental aid and dramatically increased the number of scholarships for Third World students (Lindsay 1989; Bu 2003; Unger 2011). Training the new elites, who would hold key positions in the state or party mechanisms and play a pivotal role in the economic affairs and political orientation of their countries, became a crucial objective of policy-makers in the North. Not without concern, Frantz Fanon captured the immediate consequence of the Western and Eastern interest in African and Asian elites in the following words: "The governing classes and students of underdeveloped countries are gold mines for airline companies," he commented and added: "African and Asian officials may in the same month follow a course on socialist planning in Moscow and one on the advantages of liberal economy in London or at Columbia University" (Fanon 1963: 83). The phenomenon was part of what the British Prime Minister Harold Macmillan had famously described as a peaceful "battle" between the East and the West "for the hearts and minds" of postcolonial peoples. The training of new elites epitomized this battle. With decolonization, higher education became one of the most important issues in the international cultural politics of the global Cold War (Laïdi 1986; Hobsbawm 1994; Westad 2007; Leffler \& Westad 2010). The engagement of Western and Eastern countries either directly, or through international organizations, as well as the commitment and enthusiasm of the less developed ones, contributed to the expansion of education in the Third World and played a major role in what sociologists 
of education later described as a "world educational revolution" (Meyer et al. 1977; Boli et al. 1985; Fiala \& Lanford 1987).

The Soviet Union's cooperation with Africa was one of the most important chapters of the global education revolution. This paper reopens this chapter. It is based mainly on documents from Soviet ministries, universities, party and state bodies, which became accessible to researchers after the post-1989 "archival revolution," yet whose importance with regards to the history of postcolonial Africa has not as yet been assessed. The paper maintains that the birth, the content, and the life-cycle of the Soviet-African cooperation, whose core was the Soviet aid African countries were receiving almost entirely as a grant, clearly bore the imprint of the Soviet experience and worldview, of the Cold War rivalry, and of the political circumstances sketched out above. At the same time it insists that it also bore the imprint of Africa. African political parties, student organizations, trade unions and cultural societies successfully promoted their cause and benefitted from the aid of the USSR and of other socialist countries. Thousands of students received scholarships, graduated from first-class universities and embarked on careers that changed their lives. African governments, finally, although from the position as beneficiaries, managed to impose restrictions on the donors' policies, to advance their agendas and to maximize their benefits. As this paper will argue, within a few years of its inception, and despite some tensions due to Soviet admission policies or to the teaching of MarxismLeninism, the educational exchange became a "normal," effective and predominantly state-to-state cooperation. The effects of this cooperation in terms of elites' training are presented throughout the paper, while its overall impact on Africa is discussed in the conclusion.

\section{Visions and Policies of Soviet-African Educational Cooperation}

If with decolonization, education became a prominent issue on the Soviet African agenda, it was, first and foremost, a prominent issue on the agendas of Africans. "The citizens of Africa see in education a means by which their aspirations may be met" and "they are willing to sacrifice for the attainment of this means for gaining economic and social development," stated the delegates who attended the Addis Ababa Conference of African States on the Development of Education in Africa in May 1961 in their Final Report (UNESCO 1961: 3). As Assié-Lumumba (2006) has argued, African leaders were indeed committed to "sacrifice," that is, to invest as much as possible in education. This was not only in response to domestic demands, but also because they were genuinely convinced that investment in education would bring economic development and modernization to their countries, as many prominent theorists were then preaching. The training of African professors, engineers, managers, and other specialists was undoubtedly a prerequisite for 
economic development and, for the more radical, a prerequisite for the nationalization of foreign companies. "Nationalization" of human resources, i.e., the substitution of foreigners with Africans, constituted thus a "noble" political, economic and cultural goal and Soviet experience in that field, according to the prominent Nigerien militant and scientist Abdou Moumouni (1998: 258-259), was particularly relevant. These were all empowering aspirations, but in the meantime, the reality was that economic and human resources, money and elites, were clearly missing, which made civil cooperation with developed countries urgently needed.

Under those circumstances, most African countries and especially those which had proclaimed their faith in a version of socialism more or less inspired by foreign examples, signed cultural agreements with the USSR and placed strong emphasis on educational matters. Egypt became the first African country to sign such an agreement in 1957 in order to send students to the USSR and to invite a group of seven Soviet professors to teach at the Suez Oil Institute. Guinea, Mali and Ghana followed suit. In Guinea, between 1960 and 1964, the USSR established the Polytechnic Institute of Conakry, with four faculties of engineering and an enrollment capacity of 300 students per year. In Mali, between 1963 and 1966, the Soviets also founded the Higher Administrative School of Bamako with an enrollment capacity of 250 students per year, future civil servants for the friendly regime of Modibo Keita, as well as a school of medical assistants and a center for agricultural training. All these schools were created with low-interest Soviet loans, which were quickly rescheduled and later written-off. Although they remained ill equipped and understaffed (Bartenev 2007), both the Conakry Institute and the Bamako School became the first higher education institutions in Guinea and Mali respectively and constituted landmarks in SovietAfrican cooperation. In 1964, in response to a request from the Algerian government, the USSR created the African Center of Hydrocarbons and Textiles in Boumerdes, as a gift to Algeria. The Center, which was comprised of the Oil and Gas Institute and a Textile School, became one of the most successful Soviet educational undertakings in the noncommunist world and the only one to host a sizeable community of Soviet professors. ${ }^{2}$ In 1960 , the government of Patrice Lumumba had also expressed the wish to employ 1,500 Soviet teachers and professors with knowledge of French in the Republic of Congo. This wish, however, never materialized. ${ }^{3}$

2. In 1980, there were 935 Soviet professors teaching in Algeria and almost onethird of these at the African Center of Hydrocarbons and Textile. See the report of the Soviet Ministry of Higher and Secondary Technical Education: GARF, f. 9606, op. 1, d. 9120, 1. 25-29.

3. It was extremely difficult, in the early 1960 s, to find even a handful of Soviet professors with good knowledge of foreign languages. Soviet professors sent to Africa were thus always accompanied by interpreters, generally one interpreter for every seven to ten professors, the time to learn French or English on the spot. 
Apart from the radical African governments, most Western-oriented ones also welcomed Soviet educational and technical assistance. Between 1960 and 1963, for instance, the USSR created the Bahir Dar Technical Institute as a gift to Haile Selassie's Ethiopia. In 1968, the Soviets constructed and equipped the National Engineering School of Tunisia. Both countries however refrained from employing Soviet professors, something that provoked frustration on the Soviet side. Frustration with these costly commitments and with the failure to establish permanent ties through the presence of Soviet teaching staff led the CPSU to almost halt the construction of educational institutes in Africa and, by the end of the 1960s, to concentrate on the training of African students in the USSR. ${ }^{4}$ The offer of scholarships for studies in the USSR was seen then with suspicion by several Western-oriented governments, at least during the early sixties, when they were reluctant to send students. For young African candidates, however, it was rather an extraordinary opportunity to receive higher education. And for some, it seemed to be a real chance to realize their dream and to study in the "in the motherland of socialism."

Fascination with the ideology, the international policies, and the technological achievements of the USSR was widespread among African youth. In his broad survey of the opinions, worldview and aspirations of African students in France, the Senegalese sociologist Jean-Pierre N'Diaye (1962: 228$229,243-245$ ) found that $25 \%$ of the students admired the USSR, $20 \%$ admired China, $12.4 \%$ Israel, $12 \%$ Cuba and $8 \%$ France, while the United States was lagging far behind with only $3.3 \%$ of positive responses. The reasons underpinning their admiration for the USSR were the rapid Soviet progress in all areas (35\%), communist ideology (22.3\%) and scientific achievements (18.5\%) such as the Sputnik and Lunik satellites. Accordingly, $37.8 \%$ of the students believed that "full-fledged socialism" constituted the best economic system for the development of Africa. N'Diaye's colleague, the French sociologist Pierre Fougeyrollas (1967: 156), conducted similar research among his African students at the University of Dakar to find that the USSR was not in first, but in third place, among the countries which were considered as "models," behind France and Switzerland. Third

This was a serious handicap for the Soviet cooperation with African countries. For the demand of the Congolese government, see the report of 27/01/1961 of the Soviet State Committee for Cultural Exchange with Foreign Countries: GARF, f. R-9518, op. 1, d. 585, 1. 121.

4. Algeria was an exception. Oil-rich, eager to diversify its foreign partnerships and at the same time satisfied with its cooperation with the USSR, the country continued buying low-cost Soviet educational services. During the 1970s, the USSR created the National Institute of Light Industry in Boumerdes and the Institute of Mining and Smelting at the University of Annaba. Besides, as Fahim Qubain (1966: 104-105) had earlier noticed, several Arab countries were importing laboratory equipment from the USSR, East Germany or other socialist countries because it was 50 or even $70 \%$ cheaper than the Western equipment, and also because they could often purchase it on a barter basis. 
or first, the USSR was genuinely admired, something that the thousands of letters Africans were sending to various Soviet organizations clearly demonstrate. The achievements of the cosmonauts Yuri Gagarin and German Titov were celebrated by the Uganda National Congress Youth Organization, ${ }^{5}$ the Committee of Rural Youth of Togo, ${ }^{6}$ the Madagascar-USSR friendship association, ${ }^{7}$ and by numerous African youngsters, who were applying for scholarships in order to study at universities that, in their eyes, had produced the Soviet technological miracle.

African radical organizations, political parties and trade unions, were also looking East for aid and education. Besides training executives at political schools, they were also requesting scholarships for ordinary university students, members of the party or of its youth branch. The leaders of the Union des populations du Cameroun (UPC), Félix Moumié and Ernest Ouandié, as well as Jacques N'Gom, their opponent and Secretary General of the Union générale des travailleurs kamerunais (UGTK), had been among the first to make such requests and to reap the rewards. ${ }^{8}$ Bakary Djibo, the leader of the left-wing Sawaba party of Niger, was requesting as many scholarships as possible and sending long lists of prospective students to Moscow. ${ }^{9}$ The African Party for the Independence of Guinea and Cape Verde (PAIGC) also relied on Soviet educational aid and its leader, Amilcar Cabral, was closely following up on his students. ${ }^{10}$

\section{Soviet Scholarships and African Beneficiaries}

Eager to cultivate ties and to expand their influence, the Soviets offered scholarships to three groups of recipients. The first was the group of governments, mainly the left-leaning ones, although Western-oriented governments were not at all excluded. The Soviet Ministry of Education granted these "state scholarships" to the Ghanaian, Ethiopian or Nigerian ministries,

5. Letter sent to the Chairman of the Soviet Association for Friendship with the peoples of Africa (SADNA) by A. O. Seyonga on behalf of the Uganda Youth Organization, Cairo, 15/09/1959: GARF, f. 9576, op. 12, d. 40, 1. 70.

6. Letter sent to the Soviet Committee for the Defense of Peace by F. Toula, President \& J. Amegboh, Secretary General of the Togolese committee, Lomé, 14/08/1961: GARF, f. 9539 , op. 1, d. 866, 1. 2-3.

7. Letter sent to the Soviet Society for Friendship and Cultural Exchange with Foreign Countries by the Madagascar-USSR association, Tananarive, 15/09/1959: GARF, f. 9576, op. 12, d. 40, 1. 34 .

8. See, for instance, Jacques N'Gom to L. Soloviev, Secretary of the Central Council of Trade Unions, Yaoundé, 29/07/1960: GARF, f. 5451, op. 45, d. 1559, 1. 9.

9. Bakary Djibo to M. Bakhitov 13/05/1961 and Bakhitov to Djibo, Moscow 13/06/1961. Bakhitov was secretary of the Soviet Afro-Asian Solidarity Committee: GARF, f. 9540, op. 1, d. 110, 1. 112-114 and 1. 124.

10. See Cabral's correspondence with the Soviet Committee of Youth Organizations on issues of scholarships and students, see: RGASPI, f. M-3, op. 3, d. 28, 1. 79 et 658 , d. $29,1.61$, d. $33,1.67-68$, d. $348,1.157-158$, d. $584,1.48-54$. 
which in turn were selecting future students. Only rarely did some African governments pay a small number of scholarships in addition to the scholarships granted by the USSR. Egypt was the only country to systematically pay one-third of the monthly stipend for the majority of Egyptian students. The second group was comprised of anticolonial parties of Southern and Portuguese Africa, such as the PAIGC, which were fighting for independence. The third group included African anti-governmental parties, social, cultural and other officially non-governmental organizations from countries with which the USSR maintained diplomatic relations and most often also cultural cooperation. The second and third groups were not offered state scholarships, but rather subventions from Soviet social, cultural and political organizations, which, in theory, were acting independently from the Soviet government. Included among these were organizations such as the Soviet Afro-Asian Solidarity Committee (SKSSAA), the Committee of Youth Organizations (KMO), the Union of Societies for Friendship and Cultural Exchange with Foreign Countries (SSOD) and the Central Council of Trade Unions (VTSPS). ${ }^{11}$ From the 1960 s to the 1980 s, the scholarships offered by way of such organizations made up approximately $25 \%$ of all Soviet scholarships. In 1985-1986, for instance, 5,288 of the 22,863 students from the entire African continent held scholarships granted through these organizations. ${ }^{12}$ In the second and third groups too, African recipients were selecting the future students from among their members, while the Soviets had little influence.

The UDN-Lumumba University, whose founding members had been the four Soviet organizations mentioned above, was par excellence a school recruiting the majority of its students through the channel of Soviet and African organizations and parties (second and third groups), namely with political criteria. In 1965-1966, for instance, 36 of the 152 UDN scholarships intended for Africa were offered to Oginga Odinga-who was in fact still in government-for the "progressive" members of the Kenya African National Union (KANU). Furthermore, 20 scholarships were offered to various leftleaning Nigerian organizations, such as the Nigerian Youth Congress and the Socialist Workers and Farmers Party of Nigeria (SWAFP), 6 to the Parti progressiste and to the student union from Dahomey studying at the UDN, 5 to the UPC and to the Cameroonian Student Union of the UDN, 5 to the Sawaba, 5 to the Parti africain de l'indépendance (PAI) and 8 to parties fighting against Portuguese rule. The distribution of scholarships to Arab, Asian and Latin American students was similar. ${ }^{13}$ It was thus absolutely

11. SKSSAA was the Sovetskij Komitet Solidarnosti so Stranami Azii I Afriki, KMO, the Komitet Molode nyh organizacij, SSOD, the Soiuz Obšestv Družbyi Kul'turnoj Svjazi s Zarubžymi Stranami and VCSPS, the Vsesoiuznyi Central'nyi Sovet Professional'nyh Soiuzov.

12. Annual report of the Soviet Ministry of Education based on data of January 1, 1986: GARF, f. 9606, op. 3, d. 984, 1. 9.

13. See the plan of admissions: GARF, f. 9606, op. 2, d. 177, 1. 2-7. 
true that during the 1960s the Lumumba was hosting mainly communist and leftist students, something that undoubtedly damaged its reputation (Rubinstein 1971; Koudawo 1992).

The complete picture was, at the same time, much more complex and this was true for two main reasons. First, a number of Africans attending the UDN were not members of anti-governmental parties, but students selected directly by African governments. Second, students recruited through radical parties and pro-Soviet organizations (not necessarily anti-governmental ones) were attending not only the UDN, but tens of ordinary Soviet schools. In 1965-1966 again, besides the UDN scholarships, Soviet organizations disbursed at least 240 scholarships for various African parties, student and trade unions, while the number of state scholarships (first group) was more than $1,000 .{ }^{14}$ Finally, as reflected by those numbers, for all its importance during the 1960s, the UDN was but one center for the training of African (and Third World) students. Besides the UDN, the overwhelming majority of students were studying in Moscow, Kiev, Kharkov, Leningrad and other prestigious universities, medical and technological institutes or in technical schools. Among the 20,000 black Africans who, in the second half of the 1980s, were enrolled in Soviet schools, only 5\% were at the UDN. In many respects, this development reflected the expansion of state-to-state cooperation.

Yet if most African governments welcomed Soviet aid, neither the Western-oriented, nor the radical ones approved of the distribution of scholarships to opposition parties and organizations. The third group of recipients was perceived as a threat by African regimes. In August 1961, the government of Somalia announced to the Soviet ambassador that all scholarships for Somalis should be transferred to a special office in charge of educational exchange and the government of Kwame Nkrumah did the same in 1962. ${ }^{15}$ Interestingly, it was Nkrumah's government which distrusted the unofficial recruitment channels, but which was simultaneously issuing Ghanaian passports for Nigerians and other Africans who had been granted scholarships by Soviet organizations. Nigeria, too, created an office for educational exchange and issued recurrent verbal warnings targeting both the Soviet organizations and the UDN. In addition to their protests, African countries increased border controls and warned all "clandestine" students that their diplomas would not be recognized. Last but not least, the strengthening of the one-party and gatekeeper states (Bayart 1989; Cooper 2002)

14. It should be noted, however, that the 240 scholarships of the organizations and the 1,000 state scholarships were for the entire continent and not only for SubSaharan Africa. See "Information on the distribution of scholarships by the Soviet social organizations to foreign organizations," KMO, no date: Russian State Archive of Social and Political History (hereafter RGASPI), f. M-3, op. 3, d. 33, 1. 153-154.

15. Memorandum from the Ministry of Foreign Affairs of Somalia, 16/08/1961, copy in Russian: GARF, f. R-9576, op. 14, d. 44, 1. 182-183. Letter from the Ministry of Foreign Affairs of Ghana, 06/11/1962, and a copy in Russian of a Ghanaian Note of 26/03/1963: GARF, f. R-9576, op. 14, d. 58, 1. 6 and 18. 
and their emulation of Soviet techniques of government under the guise of the socialist modernization (Copans 1984), in reality meant a crackdown on opposition parties, independent organizations and trade unions, which benefitted from Soviet aid, and their substitution by state-controlled entities and by party infrastructure. These developments had very tangible effects on the recruitment of students because scholarships intended for independent African organizations were ending up at state and party offices. The Soviet Minister of Education, Viatcheslav Elioutin, stated in 1965: "The selection of candidates for a scholarship of social organizations in Morocco, Nigeria, Somalia, Kenya and certain other countries is made by the governments of those countries and, as a result, offering social scholarships makes little sense." 16 The "government filter," as it was called in Moscow, in practice meant that often there was little difference between the 25 and the $75 \%$ of students who held social and state scholarships respectively. It also meant that African governments had managed to impose their policy in favor of the state-to-state cooperation.

The USSR never gave up recruiting communists and sympathizers. Yet it also came to terms with the new reality for several reasons. Above all, Moscow sought to avoid damaging its relationship with friendly regimes whose "socialist" practices it had to respect, as well as to avoid vindicating the suspicions of Western-oriented countries. Instead, in order to dissipate suspicion, the Soviet authorities provided African embassies with lists of almost all the names of their nationals and asked the "clandestine" students to present themselves to their embassies in order to legalize their situation. Another reason behind the Soviets' accommodation to the new circumstances was their disappointment with many students who had been selected by leftist organizations and notably with those recommended by youth unions based in the West. The Ugandan Andrew Richard Amar, for instance, who, after he was expelled from the USSR, wrote the acrimonious testimony An African in the USSR (Amar 1961), had been recommended by Dennis Phombeah, the Secretary General of the West African Students Union (WASU) and the Committee of African Organizations of the United Kingdom. ${ }^{17}$ The Senegalese Ibrahima Konaté, founder of a Pan-African union in Kiev and torchbearer of protests against racism, had been Secretary of the Fédération des étudiants d'Afrique noire en France (FEANF). ${ }^{18}$ Another former FEANF militant was the Dahomean Léopold Agboton, student at Moscow State University (MGU) until he was expelled in April 1966, Secretary General of the

16. "On the distribution of scholarships of Soviet social organizations in foreign countries" draft of a Decision, 01/05/1965: RGASPI, f. M-1, op. 46, d. 395, 1. 27.

17. Phombeah's letter of October 6, 1959 to Professor Ivan Potekhin of the SKSSAA: GARF, f. 9576 , op. 12, d. 40, 1. 152.

18. On Konaté, see a Komsomol report of 29/05/1964: RGASPI, f. M-1, op. 46, d. $403,1.81-82$. 
Union of African Students in Europe (UASE), Maoist and, according to all accounts, the most disturbing youth leader. ${ }^{19}$ Finally, by cooperating with African states, instead of recruiting blindly dubious sympathizers, some of whom were also bad students, the Soviets managed to drastically reduce the drop-out rate and to elevate the overall academic standard. Training good specialists, the future African elites, was, after all, a major objective of Soviet civil aid. Making them socialists and friends of the USSR was, of course, the other major task the CPSU had entrusted to Soviet universities and organizations.

\section{The Training of Students in the USSR}

A reader of Andrew Amar's memoirs and of other contemporary accounts may arguably assume that the Soviet hosts were obsessed with the indoctrination of students coming from non-communist countries. Perfectly fitting into the powerful Cold War mindset, this assumption, however, is not accurate. Until October 1968, all courses of political and social sciences, whose aim was indeed to inculcate Marxism-Leninism in the minds of students, were optional for all students from non-communist countries with the exception of those who were enrolled in faculties of social and political sciences. But given the huge burden the students had both at the preparatory and the specialized faculties in order to learn Russian and, for many of them, to catch up with the required academic level, and given the unpopularity of the courses in question, most students did not attend classes. Even those who were instructed by their parties or governments to do so usually disobeyed or, simply, did not sit for exams. As a result, class attendance in several schools in Moscow and Leningrad oscillated between 25 and 50\% (Katsakioris 2015: 204-205).

Aside from the discontent of Soviet faculty members and students, reactions also came from socialist African countries. The ambassador of Mali in Moscow attended the annual congress of Malian students in January 1965 and urged them to take the elective courses. ${ }^{20}$ A couple of months before, the secretary for ideological questions of the Ghanaian Convention People's Party, Kweku Akwei, angry about the poor political education of Ghanaians, expressed the following remarks to the officials at the Soviet Ministry of Education: "It is inconceivable for us that in the country of Marxism and of socialism our students are exempted from the study of social and political disciplines and that often they know much less about Marxism than our students in Manchester." Akwei added: "You say that you give the students

19. On Agboton and his expulsion, see the Decision of 23/04/1966 of the Vice-Minister of Education, N. Sofinskij: GARF, f. 9606, op. 2, d. 223, 1. 45.

20. Report on the Malian students, 29/04/1965: RGASPI, f. M-1, op. 46, d. 403, 1. 75. 
the right to decide whether to study Marxism or not. We do not agree with this. And we are not interested in what the students prefer." 21

The Soviets were also particularly frustrated with the Africans students, many of whom had staged anti-Soviet protests and expressed pro-Chinese or even pro-Western views (Hessler 2006; Matusevich 2008). Attributing these phenomena to their "petit bourgeois" worldview and their poor political education, the Ministry of Education decided, in October 1968, to make the attendance of political and ideological courses compulsory. ${ }^{22}$ From that moment on and until the curriculum reform undertaken in 1989 with the blessing of Mikhail Gorbachev, students had to follow such courses as the "History of the CPSU," the "Principles of Scientific Communism," "Political Economy" and "Scientific Atheism" (Rajaonesa 1994: 108-109). If the 1968 decision implicitly acknowledged the failure to attract students to the optional courses, its effects in terms of indoctrination should nevertheless not be overemphasized. The teaching of the non-ideological scientific disciplines remained by far the most important task of the faculty members in all institutes and universities. Indeed, the students who had a tough schedule and did not welcome the additional burden, according to all sources and accounts, were by far more concerned with concentrating on the main subjects, rather than on the ideological courses they had to take as requirements.

Studies in the USSR were longer than in the West for two main reasons. The first was that students had to spend one year and a few of them a second one at a preparatory faculty to learn Russian and take courses related to their specialization. Upon successful completion, students were admitted to the regular faculties. The second reason was that studies at the regular faculties lasted one year longer than studies at equivalent faculties in the West. The additional (fifth) year was divided between on-the-job training and the writing of the diploma thesis (diplomnyi proekt). For this reason, the first degree awarded by the Soviet university was the Magister. The exception was again the UDN, in whose faculties studies were, until the mid1970s, one year shorter. Nonetheless, UDN awarded a Magister directly to its graduates-who were also doing their on-the-job training and writing a master thesis-just like the other Soviet schools of higher education.

Once at the main faculties, Africans and other Third World students joined the student body and attended the same courses as their Soviet or Eastern European peers. Nevertheless, as their linguistic skills were still inadequate, they often had to attend additional courses to improve their Russian. At the same time, mainly as a consequence of the language gap, additional efforts were required to assimilate the content of lectures and

21. Transcript of the discussion of 28/02/1964, by S. I. Sohin, Vice-Director of the Department of Foreign Relations of the Ministry: GARF, f. R-9518, op. 1, d. 546, 1. $47-49$.

22. I found no evidence that the events of May 68 spurred the Ministry to take this decision, although I cannot exclude that they played some role. 
seminars. In practice, these additional efforts meant three things: first, that the students were taking auxiliary courses in which the lectures were repeated and explained; second, that they were joining seminars in small groups whose aim was to tackle the students' weaknesses; and third, that in the case of some students, a supervisor, either a faculty member or a Soviet student, was assigned to assist them. Students who failed to cope and fulfill the requirements were confronted with measures such as the reduction of their monthly stipend or transfer to a technical institute. Those charged with absenteeism, violation of discipline, anti-Soviet behavior, or singled out as troublemakers, could end up being expelled from the USSR.

Both the auxiliary courses and the disciplinary measures were instituted in the 1960s, when the dropout rate was particularly high. According to an analytical report on the UDN, during the period 1960-1968 over $13.8 \%$ or 690 among approximately 5,000 Third World students dropped out, the majority of them for personal or political reasons and as a consequence of disciplinary sanctions. ${ }^{23}$ The picture was very different at an elite school such as the Moscow Energy Institute (MEI), where, in 1964, the dropout rate of students from the Third World skyrocketed to $44.1 \%$. In sharp contrast with the UDN however, the MEI had such an alarming dropout rate because of its very high academic standards. The enrollment of sometimes ill-prepared students, often through political channels, created serious problems, which the MEI faculty members tried to tackle initially through auxiliary courses, almost doubling the hours of classes the students had to attend. Nevertheless, as the dropout rate remained high and as many MEI students were transferred to other less demanding Soviet schools, the rector took the decision in 1968 to halt the enrollment of Third World students in most specialized fields and to concentrate these students in a small number of faculties under the supervision of chairs (kafedry) especially created for them. In practice, this meant that Third World students had fewer options to specialize in different disciplines. It also meant that within the same specialized program they were attending the same lectures as their Soviets peers, but different seminars, and that at the end of the courses, they were taking different exams.

This decision sparked protests among the students who feared that "segregation" and the lowering of academic standards would affect their degrees. But as it reduced the dropout rate dramatically, to $7.8 \%$ in 1970, it was not called into question. ${ }^{24}$ In December 1974 the head of Central Committee's Department of Sciences and Educational Institutes of the CPSU, Sergey Kolesnikov, praised the decision and encouraged other schools to follow

23. Report of 04/06/1968 by N. Egorov and N. Sofinskij: RGASPI, f. M-1, op. 39, d. $143,1.10$.

24. Report for in-house use by the Vice-Rector S. V. Nadeždin, included in the "secret" issue $\mathrm{n}^{\circ} 39$ of 1975 produced by the Soviet Ministry of Education: RGASPI, f. M-3, op. 8, d. 1152, 1. 179-188. 
MEI's example. ${ }^{25}$ His example, however, was not followed, as at almost all universities, Africans and all Third World students were studying in the same programs with their Soviet peers.

In fact, there was no longer cause for special arrangements. During the 1970s and 1980s, the dropout rate had been drastically reduced and generally limited to the preparatory faculties. Between 1976 and 1981, for instance, only $3.8 \%$ of all Third World students enrolled at the preparatory faculty of the Kharkov State University interrupted their studies for various reasons (academic failure, health, personal reasons, disappointment and return etc.). The rest successfully completed the program, which, for ill-prepared students, who happened to come from Ethiopia, Mali, Congo-Brazzaville, Yemen and Afghanistan, included many additional hours of mathematics and natural sciences. ${ }^{26}$ As regards the regular faculties, during the academic year $1980-81$ only 12 of over 442 students $(2.7 \%)$ dropped out of the Odessa Polytechnic Institute and 2 (both Ethiopians) out of $295(0.7 \%)$ of the Medical School of Crimea. ${ }^{27}$ The spectacular decrease in the dropout rate reflected, first and foremost, the improvement of the level of students, who were selected with stricter academic criteria and through procedures agreed upon between the Soviet and African governments. Addressing an audience of Communist Youth (Komsomol) managers, Alexandr Žuganov, Secretary of the Komsomol USSR, could then affirm that the "average academic level of foreign students" was "perfectly comparable to the level of Soviet students and in certain cases even higher". 28

However, there were other factors that also contributed to the improvement of statistics, such as the favorable treatment of foreigners and the lower academic standards in certain schools. Serious concerns about the quality of training, especially of physicians, had been made public both in Africa and in the West (Dubarry 1980; Patton 1996: 242-244). Soviet internal accounts also confirmed that the training of physicians at the UDN was inadequate and that in a number of schools in Tashkent, Erevan, and Krasnodar degrees with excellent marks were indeed awarded to unqualified students (Katsakioris 2015: 202-203). A general decline in academic standards occurred by the end of the 1980s as a consequence of the Soviet collapse, and bribery and corruption were reported (Rajaonesy 2000: 178). Serious as these allegations were, such phenomena should nevertheless not yield to easy generalizations. During the greater part of the period under survey,

25. Kolesnikov's speech at a meeting of the Moscow Committee of the CPSU, on December 4, 1974: RGASPI, f. M-3, op. 8, d. 1152, 1. 158-176.

26. Report of the Rector, N. I. Sazonov, for 1980-1981: GARF, f. 9606, op. 11, d. 220, 1. 3-4, 24-26.

27. Central State Archives of Supreme Bodies of Power and Government of Ukraine (hereafter TsDAVO), f. 4621, op. 13, d. 6286, 1. 3-4 and 6282, 1. 1-3 respectively.

28. Speech of 25/04/1981: RGASPI, f. M-1, op. 39, d. 815, 1. 41. 
and for the majority of the students, studies in the USSR were difficult, serious, and demanding. If concluding the opposite played into the hands of Western-educated Africans (Koudawo 1992: 3), it certainly did not do justice to the Soviet school, nor to its African graduates.

Another important question about the Soviet-African cooperation, as important as the one of scholarships, was that of specializations. Among the 481 black Africans who graduated from preparatory faculties in 1962, $143(29.8 \%)$ were to pursue their studies in schools of medicine and pharmacology, $128(26.6 \%)$ in engineering, $55(11.4 \%)$ in economics and political economy, 28 (5.8\%) in geology, $25(5.2 \%)$ in agronomy, 17 (3.5\%) in physics and chemistry, 14 (2.9\%) in veterinary medicine, $12(2.5 \%)$ in international relations and the rest (12.3\%) in all other fields from mathematics to literature. ${ }^{29}$ In the following years, as more students on state scholarships arrived in the USSR, the percentage of students enrolled in engineering grew higher, reflecting the desires of both students and their governments, the latter viewing the training of social or political scientists in the USSR most often with distrust. For the Soviets, however, training predominantly engineers and physicians, who were less likely to occupy key positions in state mechanisms, was not serving the purpose of influencing the political course of African countries. In a report addressed to the CPSU in 1968, the Soviet Institute of Africa analyzed the issue as follows:

The main orientation [of the training programs] towards the creation of a technical and medical intelligentsia is not desirable in the future, because it does not always ensure the broad access of progressive elements into the political and social affairs of Africa. [...] Revolutionary changes are taking place in Africa for which qualified and progressive specialists are required in the sphere of administration. Practice has proven that in all African countries such specialists as economists, administrative staff, military officers, legal experts, philosophers, journalists, propaganda experts, teachers and professors constitute the principal pool, from which upper and middlerank state employees are recruited. ${ }^{30}$

However, these policy recommendations were not heeded and, as in the case of scholarships, an important reason for this was the "resistance" of African governments. Egypt, which was partly paying for the Soviet educational services, had been the first country to limit the educational exchange to just engineering and hard sciences, and other countries followed suit. Nigeria, which by the second half of the 1960s and until 1975, as a result of its partnership with Moscow during the Biafra War, became the primary African exporter of students to the USSR, completely stopped allowing the departure of holders of non-state scholarships between 1971 and 1975 and did not send a single student to study social or political sciences in the USSR. In 1974, Kolesnikov noticed the predominance of engineers (50\%)

29. TsDAVO, f. 4621, op. 6, d. 37.

30. RGASPI, f. M-1, op. 39, d. 136, 1. 85. 
and physicians (20\%) and lamented the fact that few "economists, philosophers, journalists and teachers" were being educated in the UsSR. ${ }^{31}$ This trend, however, went uninterrupted until 1991 when, according to a welldocumented survey, $53 \%$ of all foreign students were enrolled in schools of engineering (Arefiev \& Sheregui 2014: 30). ${ }^{32}$ It is true, of course, that political training continued in the schools run by the Soviet trade unions and at the Komsomol, whose graduates were sometimes admitted to ordinary universities. A third political school, created for party leaders, such as Thabo Mbeki and John Mahama, future presidents of South Africa and Ghana respectively, was the Institute of Social Sciences of the Central Committee of the CPSU. If these three schools carried on the work of universities set up by the Communist International (COMINTERN) in the interwar years, in the ordinary universities, political education was limited to the required courses of political and social sciences mentioned earlier.

In any case, despite the reactions after switching the status of these courses from options to requirements, the two other major issues, namely the control over the scholarships and the specializations, were settled in rather favorable terms for most African governments. As a result, suspicion gradually dissolved, even vis-à-vis the UDN, giving way to mutual understanding and to a "normal" and generally stable state-to-state cooperation. African governments seemed genuinely to appreciate not only the large number of scholarships their youths were offered each year, but also the "efficiency" of the Soviets and their sense of organization. Not only were Soviet authorities able to control the mobility of their nationals and maintain a very low dropout rate, there was relative calm in the USSR, the absence of phenomena such as student revolts (like May 1968 in France) and other Western temptations.

Moreover, the fact that African students in the West very often did not return to their home countries, while those in the East took a flight back upon completion of their studies-even if many of them then migrated again for further studies or work-was also an important argument in an era when the problem of the "brain drain" was looming large. To be sure, the attitude toward study in the USSR remained ambivalent and in most countries, the Soviet Magister never acquired the standing of Western diplomas (Yengo 2011). This was due to the impact of the cultural policies of Western imperialism, to anti-communist propaganda, to the dismissive attitude Western-educated Africans had vis-à-vis their Eastern-educated fellows whose competition for the same resources they did not welcome, as well as to the shortcomings

31. See RGASPI, f. M-3, op. 8, d. 1152, 1. 101 for Nigeria and 1. 161 for Kolesnikov's statement.

32. It should be stressed however that this percentage concerns not only Africans but all foreign students and that the massive arrival of Ethiopians after the revolution (1974-1978) may have altered the picture of specializations. This is a point that requires further research. 
of Soviet African policies. At the same time, however, there existed also, very clearly, a sense that Soviet educational aid was serving the needs of Africa, as well as an increased awareness of the merits of the Soviet university and of the Soviet-African cooperation.

For all these reasons, despite a few abrupt ups and downs due to regime change, such as in Ghana (1966), or due to shifts in Soviet alliances, namely from Somalia to Ethiopia (1976-1977), between 1960 and 1990 the number of African students in the USSR grew steadily and cooperation expanded to almost all African countries. Some countries received the lion's share of the aid: on one hand, there was socialist Ethiopia, which until December 1991 had trained some 4,841 students in the UsSR, followed by Congo-Brazzaville $(4,102)$, Nigeria $(3,606)$ and Mali $(2,559)$. Ivory Coast and Congo-Kinshasa, on the other hand, were the two big African countries, which restricted their cooperation with the USSR to the minimum. Between these two extremes, however, almost all countries established close ties with Moscow and benefitted from the educational aid. As a result, during the academic year 19851986 in all areas of the USSR, African students were studying in various, predominantly scientific and technological fields: 527 students from Benin, 241 from Burkina Faso, 234 from Burundi, 136 from Lesotho, 353 from Mauritania, 452 from Mozambique, 475 from Sierra Leone, 391 from Togo, 183 from Zambia, 353 from Zimbabwe, 475 from Uganda, and other groups of similar size from most African countries. ${ }^{33}$

In sharp contrast with Soviet aid to Latin America or Asia, which was heavily concentrated on Cuba, Vietnam, Mongolia and Afghanistan, diversification has been a notable feature of Soviet aid to Africa. If this was a consequence of the absence of a close and long-standing alliance, such as the one between Moscow and Havana, the fact that the Soviet-educated Africans were dispersed all around the continent and greatly outnumbered by their Western-educated colleagues, meant that the political impact of Soviet educational aid was rather limited. Another important reason-as the tables in the Appendix illustrate-was that the bulk of the Sovieteducated specialists returned to their countries of origin during the second half of the 1980s, at a moment in time when Gorbachev had already decided on the Soviet retreat from the South and that building socialism in Africa was no longer on the agenda.

In the three decades of the Soviet-African educational cooperation, which evolved against the backdrop of the well-established African dependence on the West and strong competition from Western countries, such a complex

33. For these numbers, see the sources indicated in the notes of the Appendix. 
undertaking as the transfer of the Soviet scientific and political paradigm through the training of a socialist-minded and pro-Soviet intelligentsia, had limited although very significant effects. In its early stages, the Ethiopian revolution occurred with the massive participation of students in Addis Ababa and, although active in the Ethiopian movement abroad, the few leftists who had studied in the USSR before 1974-1975, played a rather secondary role (Zewde 2014). This changed by the late 1980s, when Soviet-educated Ethiopians occupied 30\% of high offices in the Ministry of Foreign Affairs and almost $50 \%$ in Economic ministries, commissions, and state enterprises. ${ }^{34}$ The same was true for the Eastern-educated Zanzibaris (Burgess 2007) and Mozambicans who returned to their countries after independence.

Then that chapter closed and the idea to restructure the African states along socialist lines was abandoned. Thereafter, not only the collapse of communism, but also the subsequent dismantling of ties between post-Soviet Russia and Africa, seemed to vindicate the opinion that the training of Africans in the USSR failed to produce the intended political effect (Koudawo 1992). Such an ex post facto assessment of thirty years of educational cooperation from the political standpoint of the immediate post-Cold War is, however, quite problematic. On the one hand, it fails to consider the historically and quantitatively unequal terms under which Soviet-African cooperation developed against the background of Africa's dependence on the West. On the other hand, it is too quick to dismiss the potential, in terms of policy influence and networks, that might have a group of elites educated elsewhere than in the West might have had, if an alternative political and economic model turned out to be relatively efficacious and sustainable.

Speculation is, however, needless, because the Soviet-African educational cooperation did have major tangible effects, both direct and indirect, other than the Sovietization of Africa. Historians of us international relations have meticulously shown how communist involvement spurred the American government and private foundations to increase their educational aid to less developed countries and how modernization theorists who, among others, vigorously advocated the training of Third World elites, embarked on their "mission" in response to the communist challenge (Gilman 2003; Engerman et al. 2003; Ekbladh 2010). If this was an indirect effect, the direct ones were far more significant. Students from the Portuguese colonies, holders of scholarships of the Soviet Afro-Asian Solidarity Committee, studied medicine in the USSR and served in the front line of anticolonial wars.

34. "Information on the employment of Ethiopian graduates of Soviet institutes of higher education in the state apparatus of the Popular Democratic Republic of Ethiopia," 08/04/1988, based on data of the National Committee for Central Planning of Ethiopia. By A. Kurov, Second Secretary of the Soviet Embassy in Addis Ababa: GARF, f. 9661, op. 1, d. 337, 1. 1-11. 
More than 5,000 physicians from all over the continent were educated in the USSR. The "Russia Hospital" in Kisumu, Kenya, the Soviet Red Cross hospital in Addis Ababa (a gift of Stalin), and many other hospitals in Somalia, Mali, Ghana and elsewhere were staffed by graduates of Soviet medical schools. Filmmakers such as Sembène Ousmane, Souleymane Cissé and Abderrahmane Sissako studied their art in the Soviet Union, as did painters such as the Malian Mamadou Somé Coulibaly (Davis 2013) and the Beninese Philippe Abayi, his fellow countryman, the architect Joseph Vinou (Cohen 2015: 84, 75), as well as award-winning writers such as the Ghanaian Atukwei Okai and the Malian Gaoussou Diawara. Numerous lawmakers, ministers and heads of states, as the Somali President Abdiqasim Salad Hassan, the Angolan José Eduardo dos Santos, the Congolese Isidore Mvouba, the Namibian Hifikepunye Pohamba also sat on Soviet school benches. Should Eastern bloc-educated politicians be added, for example, the Kenyan Raila Odinga who studied in East Germany or the Malian Alpha Oumar Konaré who studied in Poland, the list would become very long. Beyond recalling the names of these well-known graduates, this paper has argued that the credit should first of all go to the thousands of anonymous teachers and engineers, scientists and agronomists, who studied in the USSR and then returned to Africa to practice their professions.

"The golden days of diverse scholarships for African students to study in Moscow, Prague, Warsaw, Budapest, and Belgrade seem to be almost over and rival scholarships to study in Western countries have been drastically reduced" Ali Mazrui wrote (1999: 9), adding: "The golden days of Czech, Hungarian, and Polish professors teaching at African universities are almost over and resources for Western visiting professors have been drastically reduced." This paper concludes, along with Ali Mazrui, in reiterating that Soviet educational aid has been of great importance both for the development of African countries and for several generations of African youth and that, with proper consideration, it should become clear that its effects, both direct and indirect, were major.

Bayreuth Academy of Advanced African Studies, Bayreuth (Germany). 


\section{APPENDIX}

Table 1. - Students From Sub-Saharan Africa in the Major host countries, 1962-1991

\begin{tabular}{|c|c|c|c|c|c|}
\hline Year & France & USA & USSR & UK & West Germany \\
\hline 1962 & 3,895 & 3,540 & 1,027 & 3,394 & 948 \\
\hline 1963 & 3,538 & 4,484 & 1,288 & 3,288 & 962 \\
\hline 1964 & 4,175 & 5,079 & 2,177 & 3,209 & 1,103 \\
\hline 1965 & 4,036 & 5,333 & 2,794 & 3,347 & 1,204 \\
\hline 1966 & 4,117 & 5,680 & 2,829 & 3,377 & 1,270 \\
\hline 1967 & 4,347 & 5,613 & 3,272 & 3,299 & 1,171 \\
\hline 1968 & 4,444 & 5,610 & 4,309 & 2,840 & 1,230 \\
\hline 1969 & 5,151 & 5,928 & 4,458 & 4,723 & 1,158 \\
\hline 1970 & - & 6,886 & 4,459 & 4,776 & 1,164 \\
\hline 1971 & 6,423 & 7,759 & 4,267 & 4,697 & 1,178 \\
\hline 1972 & - & 9,366 & 4,277 & 4,753 & - \\
\hline 1973 & 12,338 & 10,674 & 4,661 & - & - \\
\hline 1974 & 14,083 & 15,670 & 5,027 & 6,745 & 1,593 \\
\hline 1975 & 16,979 & 21,840 & 5,120 & 7,992 & 2,169 \\
\hline 1976 & 18,631 & 21,663 & 6,331 & 9,261 & 2,112 \\
\hline 1977 & 20,865 & 23,885 & 8,120 & 10,164 & 2,210 \\
\hline 1978 & 22,193 & 27,790 & 9,799 & 10,276 & 2,222 \\
\hline 1979 & 24,053 & 29,142 & 11,110 & 9,836 & 2,163 \\
\hline 1980 & 24,405 & - & 12,627 & 9,520 & 2,267 \\
\hline 1981 & - & 27,313 & 13,808 & 9,582 & - \\
\hline 1982 & 30,045 & - & 14,259 & - & 2,452 \\
\hline 1983 & $30,795 *$ & - & 15,318 & 7,952 & 2,654 \\
\hline 1984 & 31,513 & 28,235 & 16,571 & 7,629 & - \\
\hline 1985 & - & 24,212 & 17,378 & 7,725 & 2,853 \\
\hline 1986 & 30,132 & 23,051 & 18,118 & - & 2,869 \\
\hline 1987 & 29,254 & 23,080 & 19,410 & 7,473 & - \\
\hline 1988 & 28,532 & 18,564 & 20,904 & 7,594 & 3,161 \\
\hline 1989 & 32,092 & 17,887 & 22,719 & 8,023 & - \\
\hline 1990 & 27,503 & 17,264 & 23,809 & 7,975 & 3,762 \\
\hline 1991 & 27,191 & 17,819 & 18,336 & 8,016 & 4,160 \\
\hline
\end{tabular}

* Students from Egypt, Libya and Sudan are exceptionally included. 
Data in this table, as well as in Tables 2, 3 and 4, illustrate the aggregate number of students who were studying in the host countries during the year indicated. This means that the same student is counted in four or five subsequent years. Students at military or political schools are not included. As regards the USSR, data come from the annual tables the Soviet Ministry of Education was compiling each year, as a rule, between November and December. For the academic years (school terms) 1980-81 and 1984-85, I did not find annual tables. To calculate the number of students for these two years, I used the data of the previous year, deduced the number of students who were expected to graduate, and added the number of the newly-enrolled ones. This means that the data for these two academic years are approximate. See GARF, f. R-9606, op. 1, d. 521, 1. 42-43, d. 869, 1. 42-45, d. 1638 , 1. 9-12, d. 1948 , 1. 1-4, d. 2369, 1. 6-7a, d. 2381, 1. 1-6, d. 2699, 1. 1-5, d. 3090 , 1. 1-6, d. 3533, 1. 1-6, d. 3957, 1. 1-6, d. 4387, 1. 1-6, d. 5938, 1. 1-6, d. 6485, 1. $1-6$, d. 6841 , 1. 1-8, d. 7244 , 1. 1-8, d. 7663 , 1. 1-7, d. 8151 , 1. 2-6, d. 8660, 1. 1721, d. 9122 , 1. 7-11, d. 9524 , 1. 1-8, d. 10011, 1. 1-5, and op. 3, d. 608, 1. 4-10, d. 984, 1. 8-14, d. 1368, 1. 6-10, d. 1723, 1. 1-7. Also GARF, f. R-9661, op. 1, d. 335, 1. 713, d. 589, 1. 1-7, d. 772, 1.1-6, d. 851, 1. 3-10. And RGASPI, f. M-3, op. 8, d. 1152, 1. 104. As regards the other countries, data come from the three volumes of UNESCO, entitled Statistics of Students Abroad 1962-1968, 1969-1973 and 19741978, as well as from the UNESCO Statistical Yearbook of every year from 1979 to 1993. As it is noticed in all UNESCO yearbooks, data provided "are to be considered as indicative." Data on foreign students in France, for instance, are clearly underestimated, because as a rule they did not include "students enrolled at institutions considered... as non-university ('grandes écoles', 'classes préparatoires aux grandes écoles' and 'sections de techniciens supérieurs')." Closer to the Soviet data are those on foreign students in the UK, which include "foreign students enrolled at universities (for full-time study or research), technical colleges (advanced courses) and colleges of education." For the US it should be noted that the data of UNESCO are lower compared to those of the New York Institute of International Education, yet the latter also include students at military colleges and academies. For this reason, I chose to use UNESCO's data. (-) means no data. 
Table 2. - Students from selected countries of West and Central Africa IN THE SOVIET Union, 1959-1991

\begin{tabular}{|c|c|c|c|c|c|c|c|c|c|c|c|c|c|}
\hline $\begin{array}{c}\text { C } \\
\text { o } \\
\mathbf{u} \\
\mathbf{n} \\
\mathbf{t} \\
\mathbf{r} \\
\mathbf{y} \\
\text { School } \\
\text { Term } \\
(19--)\end{array}$ & 浇 & 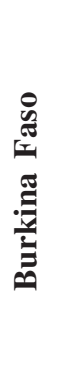 & 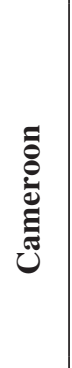 & 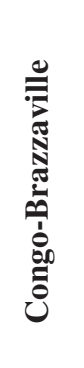 & 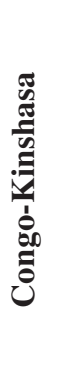 & 胥 & 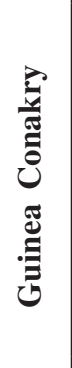 & $\begin{array}{l}\overrightarrow{\tilde{a}} \\
\tilde{0} \\
\dot{0} \\
\overrightarrow{0} \\
\overrightarrow{0}\end{array}$ & 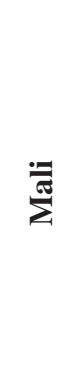 & & 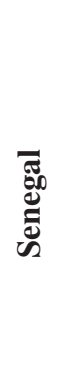 & 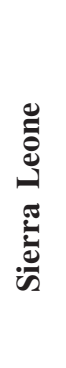 & 禺 \\
\hline $59-60$ & 1 & 0 & 13 & 0 & 3 & 14 & 62 & 1 & 4 & 5 & 3 & 6 & 1 \\
\hline $60-61$ & 1 & 0 & 38 & 0 & 6 & 108 & 69 & 9 & 20 & 27 & 7 & 22 & 20 \\
\hline 61-62 & 6 & 2 & 66 & 0 & 64 & 211 & 110 & 21 & 102 & 62 & 19 & 29 & 39 \\
\hline $62-63$ & 7 & 2 & 58 & 0 & 79 & 358 & 89 & 17 & 203 & 69 & 16 & 30 & 32 \\
\hline 63-64 & 47 & 7 & 86 & 0 & 60 & 513 & 156 & 23 & 152 & 220 & 27 & 47 & 53 \\
\hline 64-65 & 44 & 11 & 96 & 7 & 80 & 543 & 154 & 29 & 148 & 180 & 23 & 59 & 60 \\
\hline $65-66$ & 51 & 9 & 88 & 12 & 101 & 470 & 185 & 28 & 160 & 287 & 24 & 58 & 60 \\
\hline 66-67 & 55 & 9 & 93 & 117 & 49 & 425 & 96 & 25 & 173 & 392 & 17 & 108 & 58 \\
\hline $67-68$ & 64 & 6 & 119 & 288 & 45 & 357 & 178 & 35 & 210 & 615 & 16 & 257 & 58 \\
\hline 68-69 & 64 & 6 & 115 & 277 & 64 & 284 & 92 & 42 & 249 & 668 & 32 & 310 & 63 \\
\hline $69-70$ & 54 & 15 & 99 & 291 & 60 & 208 & 29 & 52 & 213 & 749 & 41 & 346 & 73 \\
\hline $70-71$ & 37 & 25 & 90 & 294 & 41 & 126 & 70 & 56 & 17 & 83 & 52 & 350 & 68 \\
\hline $71-72$ & 26 & 40 & 65 & 327 & 75 & 69 & 64 & 60 & 220 & 797 & 81 & 326 & 81 \\
\hline $72-73$ & 36 & 76 & 53 & 522 & 69 & 36 & 59 & 41 & 227 & 734 & 131 & 292 & 115 \\
\hline 73-74 & 49 & 113 & 50 & 595 & 78 & 40 & 75 & 34 & 302 & 715 & 152 & 239 & 135 \\
\hline $74-75$ & 75 & 133 & 62 & 557 & 15 & 73 & 113 & 102 & 274 & 686 & 175 & 192 & 161 \\
\hline $75-76$ & 121 & 174 & 123 & 792 & 36 & 147 & 300 & 112 & 337 & 706 & 215 & 173 & 179 \\
\hline 76-77 & 188 & 218 & 151 & 923 & 47 & 240 & 460 & 131 & 488 & 698 & 206 & 181 & 218 \\
\hline $77-78$ & 238 & 272 & 160 & 1,088 & 48 & 309 & 690 & 138 & 499 & 781 & 191 & 220 & 267 \\
\hline 78-79 & 314 & 293 & 160 & 1,123 & 48 & 412 & 788 & 122 & 635 & 861 & 184 & 244 & 292 \\
\hline $79-80$ & 345 & 263 & 160 & 1,276 & 45 & 481 & 892 & 98 & 702 & 963 & 173 & 313 & 325 \\
\hline $80-81$ & 377 & 301 & 126 & 1,303 & 52 & 543 & 927 & 56 & 719 & 1,058 & 130 & 346 & 325 \\
\hline 81-82 & 424 & 210 & 89 & 1,396 & 59 & 626 & 659 & 21 & 723 & 1,124 & 104 & 420 & 355 \\
\hline $82-83$ & 484 & 159 & 47 & 1,467 & 64 & 710 & 521 & 6 & 764 & 1,102 & 104 & 418 & 372 \\
\hline 83-84 & 480 & 127 & 26 & 1,540 & 57 & 778 & 484 & 4 & 814 & 1,007 & 114 & 463 & 384 \\
\hline 84-85 & 518 & 188 & 50 & 1,474 & 71 & 759 & 374 & 9 & 893 & 1,119 & 124 & 478 & 388 \\
\hline $85-86$ & 527 & 241 & 115 & 1,481 & 84 & 865 & 327 & 15 & 1,074 & 1,162 & 135 & 475 & 391 \\
\hline 86-87 & 587 & 250 & 192 & 1,582 & 110 & 912 & 410 & 18 & 1,252 & 1,518 & 151 & 468 & 406 \\
\hline \begin{tabular}{|l|}
$87-88$ \\
\end{tabular} & 576 & 383 & 246 & 1,628 & 146 & 949 & 501 & 39 & 1,392 & 1,348 & 102 & 545 & 391 \\
\hline 88-89 & 652 & 530 & 298 & 1,663 & 172 & 970 & 583 & 43 & 1,561 & 1,543 & 223 & 625 & 411 \\
\hline $89-90$ & 690 & 638 & 347 & 1,708 & 190 & 1,087 & 637 & 52 & 1,621 & 1,650 & 235 & 666 & 406 \\
\hline $90-91$ & 560 & 491 & 321 & 1,31 & 140 & 846 & 430 & 43 & 1,318 & 1,320 & 229 & 415 & 337 \\
\hline
\end{tabular}


Table 3. - Students from selected countries of Eastern, Central East, And Southern Africa In the Soviet Union, 1959-1991

\begin{tabular}{|c|c|c|c|c|c|c|c|c|c|c|c|}
\hline \multirow{2}{*}{$\begin{array}{c}\mathbf{C} \\
\mathbf{o} \\
\mathbf{u} \\
\mathbf{n} \\
\mathbf{t} \\
\mathbf{r} \\
\mathbf{y} \\
\text { School } \\
\text { Term } \\
(19--)\end{array}$} & \multicolumn{5}{|c|}{ East \& Central East } & \multicolumn{2}{|c|}{ Horn } & \multicolumn{4}{|c|}{ East \& South } \\
\hline & 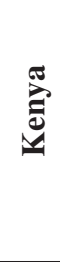 & & 苞 & 串 & 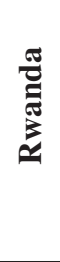 & 恶 & 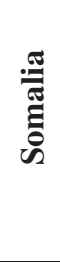 & 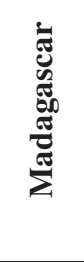 & 㞯 & 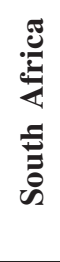 & $\begin{array}{l}\text { है } \\
\text { है } \\
\text { है } \\
\text { है }\end{array}$ \\
\hline $59-60$ & 0 & 4 & 6 & 0 & 0 & U & 23 & 1 & 1 & 0 & 0 \\
\hline $60-61$ & 13 & 11 & 9 & 0 & 1 & 7 & 25 & 2 & 5 & 2 & 1 \\
\hline $61-62$ & 27 & 38 & 11 & 0 & 4 & 22 & 118 & 3 & 11 & 3 & 9 \\
\hline $62-63$ & 48 & 105 & 7 & 0 & 5 & 40 & 131 & 4 & 11 & 4 & 5 \\
\hline 63-64 & 106 & 160 & 27 & 2 & 14 & 49 & 293 & 8 & 27 & 24 & 10 \\
\hline $64-65$ & 351 & 200 & 46 & 27 & 15 & 65 & 324 & 5 & 33 & 33 & 19 \\
\hline $65-66$ & 311 & 194 & 52 & 29 & 26 & 62 & 322 & 3 & 36 & 35 & 26 \\
\hline 66-67 & 453 & 239 & 85 & 41 & 38 & 71 & 371 & 3 & 42 & 31 & 15 \\
\hline $67-68$ & 470 & 236 & 191 & 67 & 72 & 101 & 499 & 7 & 62 & 30 & 36 \\
\hline 68-69 & 448 & 203 & 216 & 87 & 96 & 120 & 441 & 9 & 69 & 25 & 32 \\
\hline $69-70$ & 333 & 164 & 258 & 97 & 118 & 193 & 397 & 14 & 75 & 21 & 28 \\
\hline 70-71 & 203 & 134 & 253 & 110 & 121 & 214 & 328 & 20 & 86 & 15 & 20 \\
\hline 71-72 & 151 & 130 & 241 & 115 & 125 & 263 & 283 & 20 & 96 & 19 & 16 \\
\hline $72-73$ & 143 & 153 & 222 & 138 & 145 & 291 & 264 & 39 & 114 & 23 & 19 \\
\hline 73-74 & 158 & 209 & 192 & 123 & 163 & 324 & 250 & 84 & 119 & 19 & 23 \\
\hline 74-75 & 134 & 284 & 167 & 108 & 161 & 345 & 196 & 102 & 115 & 19 & 18 \\
\hline $75-76$ & 133 & 311 & 171 & 109 & 169 & 328 & 23 & 174 & 115 & 23 & 27 \\
\hline 76-77 & 178 & 418 & 202 & 122 & 174 & 647 & 284 & 234 & 115 & 28 & 42 \\
\hline $77-78$ & 207 & 478 & 237 & 125 & 178 & 923 & 335 & 378 & 126 & 49 & 49 \\
\hline 78-79 & 256 & 546 & 298 & 129 & 172 & 1,223 & 94 & 608 & 122 & 74 & 69 \\
\hline 79-80 & 294 & 547 & 320 & 120 & 145 & 1,595 & 76 & 869 & 93 & 73 & 122 \\
\hline $80-81$ & 313 & 572 & 344 & 131 & 144 & 1,880 & 74 & 989 & 116 & 93 & 144 \\
\hline 81-82 & 317 & 591 & 362 & 138 & 134 & 2,139 & 76 & 1,279 & 130 & 106 & 166 \\
\hline $82-83$ & 315 & 626 & 384 & 162 & 152 & 2,453 & 46 & 1,434 & 143 & 150 & 241 \\
\hline 83-84 & 300 & 649 & 414 & 182 & 185 & 2,733 & 40 & 1,555 & 153 & 159 & 302 \\
\hline 84-85 & 291 & 644 & 460 & 198 & 195 & 2,790 & 36 & 1,615 & 166 & 132 & 344 \\
\hline $85-86$ & 266 & 672 & 475 & 234 & 475 & 3,020 & 45 & 1,579 & 178 & 126 & 353 \\
\hline 86-87 & 223 & 590 & 461 & 275 & 290 & 3,142 & 39 & 1,518 & 206 & 102 & 376 \\
\hline $87-88$ & 204 & 609 & 408 & 319 & 305 & 3,322 & 82 & 1,501 & 207 & 87 & 374 \\
\hline 88-89 & 199 & 636 & 448 & 341 & 339 & 3,442 & 172 & 1,574 & 227 & 60 & 366 \\
\hline $89-90$ & 182 & 618 & 499 & 365 & 359 & 3,484 & 201 & 1,624 & 221 & 49 & 307 \\
\hline 90-91 & 131 & 486 & 335 & 296 & 280 & 2,448 & 151 & 1,260 & 170 & 16 & 223 \\
\hline
\end{tabular}

* For the period 1959-1964, students from Zanzibar are added to those from Tanganyika. 
Table 4. - Students from the Portuguese-Speaking African countries IN THE SOVIET UNION, 1960-1991

\begin{tabular}{|c|c|c|c|c|c|}
\hline $\begin{array}{l}\text { Country } \\
\begin{array}{c}\text { Academic } \\
\text { Year }\end{array} \\
\end{array}$ & $\begin{array}{l}\frac{\pi}{0} \\
\stackrel{0}{0} \\
\sum\end{array}$ & 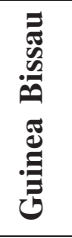 & 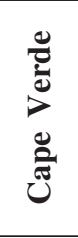 & 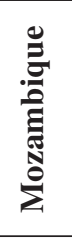 & 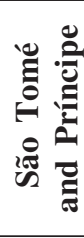 \\
\hline $1960-61$ & 0 & \multicolumn{2}{|c|}{2} & 0 & 0 \\
\hline 1961-62 & 6 & \multicolumn{2}{|c|}{6} & 0 & 0 \\
\hline $1962-63$ & 4 & \multicolumn{2}{|c|}{6} & 0 & 0 \\
\hline 1963-64 & 42 & \multicolumn{2}{|c|}{42} & 8 & 0 \\
\hline 1964-65 & 88 & \multicolumn{2}{|c|}{23} & 5 & 0 \\
\hline $1965-66$ & 53 & \multicolumn{2}{|c|}{38} & 11 & 0 \\
\hline 1966-67 & 68 & \multicolumn{2}{|c|}{74} & 16 & 0 \\
\hline 1967-68 & 76 & \multicolumn{2}{|c|}{33} & 18 & 0 \\
\hline 1968-69 & 57 & \multicolumn{2}{|c|}{33} & 16 & 0 \\
\hline $1969-70$ & 42 & \multicolumn{2}{|c|}{71} & 14 & 0 \\
\hline 1970-71 & 37 & \multicolumn{2}{|c|}{12} & 14 & 0 \\
\hline 1971-72 & 44 & \multicolumn{2}{|c|}{26} & 10 & 0 \\
\hline 1972-73 & 41 & \multicolumn{2}{|c|}{67} & 8 & 0 \\
\hline 1973-74 & 36 & \multicolumn{2}{|c|}{72} & 8 & 0 \\
\hline 1974-75 & 32 & \multicolumn{2}{|c|}{138} & 5 & 0 \\
\hline 1975-76 & 29 & 155 & 43 & 6 & 0 \\
\hline 1976-77 & 88 & 125 & 92 & 6 & 3 \\
\hline 1977-78 & 152 & 128 & 123 & 95 & 1 \\
\hline 1978-79 & 177 & 135 & 126 & 96 & 9 \\
\hline 1979-80 & 304 & 172 & 156 & 95 & 30 \\
\hline 1980-81 & 385 & 213 & 139 & 110 & 42 \\
\hline 1981-82 & 451 & 273 & 119 & 128 & 74 \\
\hline $1982-83$ & 610 & 337 & 123 & 239 & 108 \\
\hline 1983-84 & 875 & 459 & 133 & 368 & 147 \\
\hline 1984-85 & 860 & 486 & 167 & 335 & 144 \\
\hline 1985-86 & 1,033 & 541 & 149 & 452 & 151 \\
\hline 1986-87 & 1,346 & 622 & 173 & 582 & 150 \\
\hline 1987-88 & 1,604 & 654 & 208 & 694 & 157 \\
\hline 1988-89 & 1,938 & 704 & 211 & 657 & 161 \\
\hline 1989-90 & 2,018 & 720 & 275 & 743 & 166 \\
\hline 1990-91 & 1,701 & 563 & 211 & 582 & 127 \\
\hline
\end{tabular}


Table 5. - Graduates of Soviet Universities and Technical Institutes

\begin{tabular}{|c|c|c|c|c|c|}
\hline Countries & 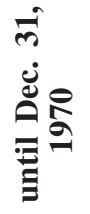 & 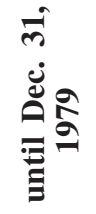 & 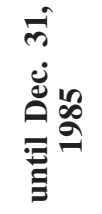 & 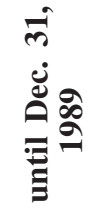 & 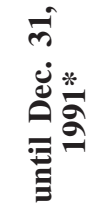 \\
\hline Angola & 51 & 113 & 645 & 1,531 & 2,228 \\
\hline Benin & 44 & 128 & 532 & 910 & 1,131 \\
\hline Burkina Faso & 5 & 136 & 376 & 449 & 588 \\
\hline Burundi & 27 & 200 & 332 & 476 & 575 \\
\hline Cameroon & 108 & 205 & 381 & 409 & 509 \\
\hline Cape Verde & - & 8 & 190 & 301 & 382 \\
\hline Central African Republic & 7 & 364 & 373 & 382 & 382 \\
\hline Chad & 1 & 264 & 603 & 834 & 940 \\
\hline Congo-Brazzaville & 112 & 1,057 & 2,588 & 3,580 & 4,102 \\
\hline Congo-Kinshasa & 56 & 127 & 198 & 233 & 272 \\
\hline Ethiopia & 51 & 450 & 2,089 & 3,782 & 4,841 \\
\hline Equatorial Guinea & 0 & 101 & 242 & 313 & 401 \\
\hline Ghana & 444 & 626 & 1,146 & 1,708 & 2,002 \\
\hline Guinea Bissau & 68 & 258 & 580 & 1,073 & 1,322 \\
\hline Guinea Conakry & 126 & 272 & 1,095 & 1,507 & 1,821 \\
\hline Ivory Coast & 33 & 145 & 228 & 230 & 243 \\
\hline Kenya & 318 & 611 & 864 & 1,068 & 1,144 \\
\hline Madagascar & - & 129 & 964 & 1,848 & 2,401 \\
\hline Mali & 167 & 597 & 1,394 & 1,996 & 2,559 \\
\hline Mauritania & 3 & 117 & 413 & 651 & 770 \\
\hline Mauritius & 48 & 210 & 351 & 454 & 531 \\
\hline Mozambique & 14 & 27 & 232 & 640 & 880 \\
\hline Niger & 46 & 117 & 249 & 286 & 340 \\
\hline Nigeria & 304 & 1,344 & 2,374 & 3,133 & 3,606 \\
\hline Rwanda & 31 & 228 & 416 & 566 & 681 \\
\hline São Tomé and Príncipe & 0 & 0 & 57 & 153 & 207 \\
\hline Senegal & 21 & 44 & 374 & 435 & 510 \\
\hline Sierra Leone & 66 & 507 & 851 & 1,183 & 1,343 \\
\hline Somalia & 302 & 720 & 772 & 815 & 831 \\
\hline South Africa & 30 & 68 & 135 & 230 & 241 \\
\hline Tanzania & 236 & 494 & 996 & 1,399 & 1,599 \\
\hline Togo & 56 & 210 & 573 & 846 & 993 \\
\hline Uganda & 60 & 364 & 60 & 914 & 1,033 \\
\hline Zambia & 15 & 126 & 316 & 443 & 492 \\
\hline Zimbabwe & 24 & 60 & 245 & 472 & 583 \\
\hline $\begin{array}{l}\text { TOTAL } \\
\text { Sub-Saharan Africa }\end{array}$ & 2,921 & 10,579 & 24,429 & 36,146 & 43,562 \\
\hline
\end{tabular}

* For the years 1990 and 1991, I did not find exact data on graduates. I thus used the data on students who were "expected to graduate." 


\section{BIBLIOGRAPHY}

AMAR, A.-R.

1961 An African in Moscow (London: Ampersand).

Arefiev, A. L. \& Sheregui, F. E. (eds.)

2014 Eksport rossijskih obrazovatel'nyh uslug. Statističeski sbornik (Export of Russian Educational Services. Statistical Collection) (Moscow: Ministry of Education and Science of the Russian Federation).

Assié-Lumumba, N. T.

2006 Higher Education in Africa. Crises, Reforms and Transformation (Dakar: CODESRIA).

BARGHOORN, F. C.

1960 The Soviet Cultural Offensive. The Role of Cultural Diplomacy in Soviet Foreign Policy (Westport: Greenwood Press).

BARTENEV, V.

2007 'L'URSS et l'Afrique noire sous Khrouchtchev: la mise à jour des mythes de la coopération," Outre-Mers. Revue d'histoire (95) 354-355: 63-82.

BAYART, J.-F.

1989 L'État en Afrique. La politique du ventre (Paris: Fayard).

BoLI, J. ET AL.

1985 "Explaining the Origins and Expansion of Mass Education," Comparative Education Review 29 (2): 145-170.

Bu, L.

2003 Making the World Like Us: Education, Cultural Expansion, and the American Century (Westport: Praeger).

BuRgESS, T.

2007 "A Socialist Diaspora: Ali Sultan Issa, the Soviet Union, and the Zanzibari Revolution," in M. Matusevich (ed.), Africa in Russia, Russia in Africa: Three Centuries of Encounters (Trenton: Africa World Press): 263-291.

COHEN, S.

2015 "Arts et pouvoirs politique et religieux en République populaire du Bénin: les quêtes d'une authenticité béninoise, 1972-1990," Master's thesis (Paris: Université Paris I-Panthéon Sorbonne).

COOPER, F.

2002 Africa since 1940: The Past of the Present (Cambridge: Cambridge University Press).

COPANS, J.

1984 “L’URSS, alibi ou instrument des états d'Afrique noire?," in Z. LAïDI (dir.), L'URSS vue du Tiers Monde (Paris: Karthala): 51-70. 
Davidson, A. \& MAzov, S. (EDS.)

1999 Rossija i Afrika. Dokumenty i materialy, XVIII v.-1960 g., v. 2 (Russia and Africa. Documents and Archival Material, 18 ${ }^{\text {th }}$ Century-1960) (Moscow: IVI RAN).

DAVIS, P. R.

2013 “'Coulibaly's Cosmopolitanism in Moscow: Mamadou Somé Coulibaly and the Surikov Academy Paintings, 1960s-1970s," in E. Rosenhaft \& R. AitKen (eds.), Africa in Europe: Studies in Transnational Practice in the Long Twentieth Century (Liverpool: Liverpool University Press): 142-161.

DUBARRY, J.-J.

1980 "Le curriculum universitaire d'un étudiant en médecine en URSS," Histoire des sciences médicales 14: 383-386.

EKBLADH, D.

2010 The Great American Mission. Modernization and the Construction of an American World Order (Princeton: Princeton University Press).

ENGerman, D. C. ET AL. (EDS.)

2003 Staging Growth. Modernization, Development and the Global Cold War (Amherst: University of Massachusetts Press).

FANON, F.

1963 The Wretched of the Earth, pref. J.-P. Sartre (New York: Grove Press).

FiAla, R. \& LANFORD, A. G.

1987 "Educational Ideology and the World Educational Revolution, 1950-1970," Comparative Education Review 31 (3): 315-332.

Fougeyrollas, P.

1967 Modernisation des hommes. L'exemple du Sénégal (Paris: Flammarion).

GiLman, N.

2003 Mandarins of the Future. Modernization Theory in Cold War America (Baltimore: The John Hopkins University Press).

HESSLER, J.

2006 "Death of an African Student in Moscow. Race, Politics, and the Cold War," Cahiers du Monde russe 47 (1-2): 33-64.

Hobsbawm, E.

1994 L'Âge des extrêmes. Histoire du court XX siècle (Paris: éditions ComplexeLe Monde diplomatique).

KATSAKIORIS, C.

2015 Leçons soviétiques: la formation des étudiants africains et arabes en URSS pendant la guerre froide, Thèse de doctorat (Paris: EHESS). 
Koudawo, F.

1992 La formation des cadres africains en Europe de l'Est depuis 1918 (Paris: L'Harmattan).

LAÏDI, Z.

1986 Les contraintes d'une rivalité. Les superpuissances et l'Afrique 1960-1986 (Paris: La Découverte).

LefFler, M. P. \& Westad, O. A. (EDs.)

2010 The Cambridge History of the Cold War, 1-3 (Cambridge: Cambridge University Press).

LINDSAY, B.

1989 "Integrating International Education and Public Diplomacy: Creative Partnerships or Ingenious Propaganda?," Comparative Education Review 33 (4): 423-436.

Matusevich, M.

2008 "Journeys of Hope: African Diaspora and the Soviet Society," African Diaspora 1: $53-85$.

MAzrui, A. A.

1999 "From Slave Ship to Space Ship: African between Marginalization and Globalization," African Studies Quarterly 2: 5-11.

Meyer, J. ET AL.

1977 “The World Educational Revolution, 1950-1970," Sociology of Education 50 (4): 242-258.

Mid SSSR (Ministry OF ForeIgn AfFAirs OF THE USSR)

1963 SSSR $i$ Strany Afriki, 1946-1962 gg. Dokumenty $i$ materialy v. 2 (USSR and the African Countries, 1945-1962. Documents and Archival Material) (Moscow: Gosudarstvennoe Izdatel'stvo Političeskoj Literatury).

Moumouni, A.

1998 [1964] L'éducation en Afrique, pref. J. Ki-Zerbo (Paris: Présence Africaine).

N'DiAYE, J.-P.

1962 Enquête sur les étudiants noirs en France (Paris: Présence Africaine).

PAtTon, A.

1996 Physicians, Colonial Racism, and Diaspora in West Africa (Gainesville: University Press of Florida).

QubAIN, F. I.

1966 Education and Science in the Arab World (Baltimore: The John Hopkins Press).

RAJAONESA, G.

1994 "Être étudiant malgache en URSS (Analyse d'ensemble et vision particulière)," Études Océan indien 18: 103-125. 
RAJAONESY, B. V.

2000 "Langue nationale, langue maternelle: un enjeu politique," in C. AlLIBERT \& N. RAJAONARIMANANA (dir.), L'extraordinaire et le quotidien. Variations anthropologiques. Hommage au Professeur Pierre Vérin (Paris: Karthala): 173-180.

Rubinstein, A.

1971 "Lumumba University: An Assessment," Problems of Communism 20 (6): 64-69.

Silm-Moskovotina, A. \& Dobronravin, N.

2015 "Des élites africaines entre deux mondes. Impact de la formation en URSS ou poids du milieu social d'origine?," in M. DE Saint Martin, G. Scarfò Ghellab \& K. Mellakh (dir.), Étudier à l'Est. Expériences de diplômés africains (Paris: Karthala): 275-287.

StAnis, V. F.

1982 “The Friendship University," Higher Education in Europe 7 (1): 16-19.

UNESCO

1961 Conference of African States on the Development of Education in Africa, 15-21 May 1961. Final Report (Paris: UNESCO).

1971 Statistics of Students Abroad 1962-1968 (Paris: UNESCO).

1976 Statistics of Students Abroad 1969-1973 (Paris: UNESCO).

1982 Statistics of Students Abroad 1974-1978 (Paris: UNESCO).

1979-1994 Statistical Yearbooks 1978-1992 (Paris: UNESCO).

UNGER, C.

2011 "USA, Decolonization and Third World Elites," in J. DüLFFER \& M. FREY (eds.), Elites and Decolonization in the Twentieth Century (Basingstoke: Palgrave Macmillan): 241-261.

Westad, O. D.

2007 The Global Cold War. Third World Interventions and the Making of Our Times (Cambridge: Cambridge University Press).

YENGO, P.

2011 "Jalons pour une historiographie des élites africaines formées dans le Bloc soviétique," in M. LECLERC-Olive ET AL. (dir.), Les mondes universitaires face au marché. Circulation des savoirs et pratiques des acteurs (Paris: Karthala): 135-148.

ZEWDE, B.

2014 The Quest for Socialist Utopia. The Ethiopian Student Movement c. 19601974 (Oxford: James Currey). 


\section{ABSTRACT}

This paper examines the history of the Soviet-African educational cooperation during the Cold War and focuses mainly on the training of African students at Soviet universities. It analyzes the ideas, aspirations and motives that governed the cooperation both in Africa and in the USSR. As regards the African side of the interaction, it draws a distinction between different actors, such as governments, opposition parties, national liberation movements and student organizations. Contrary to many assumptions and stereotypes, the paper downplays the importance of Marxist-Leninist indoctrination. It argues that the training programmes aimed to educate, not only "friends" of the Soviet Union, but notably qualified specialists who would both embody and defend the superiority of socialism and of the Soviet university system. By the end of the 1960s, most African governments had managed to impose their control over and their own criteria for the selection of students. This made Soviet aid even more attractive. The conclusion traces the impact of Soviet aid on Africa. The Appendix provides new data on African students in the USSR, on returning students, as well as suggestive comparative data on African students in major host countries.

\section{RÉSUMÉ}

La création d'une intelligentsia socialiste: la subvention des études universitaires soviétiques et son impact sur l'Afrique, 1960-1991. — L'article examine l'histoire de la coopération éducative entre I'URSS et I'Afrique pendant la Guerre froide, se concentre sur la formation des cadres africains dans les universités soviétiques, et analyse les idées, les aspirations et les motivations qui orientaient la coopération aussi bien en Afrique qu'en URSS. Loin de tout monolithisme, il distingue du côté africain, les différents acteurs : gouvernements, partis d'opposition, mouvements de libération nationale et organisations étudiantes. Et du côté de I'URSS, à I'encontre des stéréotypes, il dédramatise l'importance de l'endoctrinement marxiste-léniniste ; l'objectif des formations n'était en effet pas seulement de faire des étudiants des "amis" de I'URSS, mais aussi de former de bons spécialistes qui défendraient et surtout prouveraient grâce à leurs connaissances la supériorité du socialisme et de I'université soviétique. Vers la fin des années 1960, la plupart des gouvernements africains avaient réussi à imposer leur contrôle et leurs critères sur la sélection des étudiants, ce qui rendit l'aide de I'URSS encore plus attractive. La conclusion évoque l'impact de I'aide soviétique en Afrique, notamment sur la formation des élites. En annexe, des données inédites sur les effectifs des étudiants africains formés en URSS selon le pays d'origine, sur le retour des diplômés dans leur pays, ainsi que des données comparatives sur les étudiants africains dans les plus grands pays d'accueil.

Keywords/Mots-clés : Soviet Union, African students, Cold War, cooperation, education/Union soviétique, étudiants africains, Guerre froide, coopération, formation. 
